\title{
Effect of Integrated Nutrient Management on Leaf Nutrient Status of Walnut (Juglans regia L.)
}

\author{
B.P. Bhattarai ${ }^{1}$ and C.S. Tomar ${ }^{2}$ \\ ${ }^{1}$ Himalayan College of Agriculture Science and Technology, Ghaththaghar, Bhaktapur, Nepal \\ ${ }^{2}$ Dr.Y. S. Parmar University of Horticulture and Forestry, Nauni-Solan (H.P.)-173 230 India \\ e-mail: bishnu_horti@yahoo.com
}

\begin{abstract}
The study was conducted at 10 - years- old walnut orchard at Dr. Y. S. Parmar University of Horticulture and Forestry, Nauni-Solan(H.P.) to find out the effect of integrated nutrient management on leaf nutrient status of walnut (Juglans regia L.). There were 13 different treatment combinations of organic and inorganic fertilizers. Treatments were applied on per tree basis. Among the treatments recommended dose of NPK $+50 \mathrm{~kg}$ vermicompost and three fourth recommended dose of NPK $+68.75 \mathrm{~kg}$ vermicompost were effective for improvement of leaf nutrient status.
\end{abstract}

Key words: NPK, neem cake, vermicompost, leaf nutrient

\section{Introduction}

Walnut (Juglans regia L.) is one of the most important income generating high value nut crops and suitable for poor farmers in high hills of Nepal and India (Chaudhary et al. 2004). However, the production of walnut is very low as compared to USA, China, France and others developed countries. The annual production of walnut in USA is 290300 , China 503000 and France 34228 , but in Nepal its production is 4521 (FAO 2007). Although the demands of walnut have been increasing day by day in national and international market, farmers are not encouraged to grow this high value crop in a commercial scale. Due to lack to appropriate management practices, suitable varieties and market linkage Nepali and Indian farmers are not motivated to grow this crop.

Fertilizers and organic manures constitute important inputs in the production of fruit crops. Plants require essential mineral nutrients to complete their life cycle and the quantities required for optimum growth and production vary with species.

Increased chemical fertilizer cost and awareness of environmental pollution have necessitated the use of organic fertilizers for the development of more efficient fertility management program. Organic fertilizers are apparently environment and farmer friendly renewable source of non-bulky, low cost organic agricultural inputs for improving soil fertility status in sloppy and denuded areas. Organic manures are fairly good source of nutrients which has direct influence on plant growth like other commercial fertilizers. Mukherjee et al. (1991) and Prasad and Singhania (1989) also reported that application of organic manures with NPK increased the leaf nutrient status of Khasi mandarin. Jambhekar (1992) and Shivputra et al. (2004) also reported similar result. However, few information are available in this area; therefore this study was designed and conducted to identify the effect of INM on leaf status of walnut.

\section{Materials and Methods}

The study was conducted during 2004-2005 at the walnut orchard of the Department of Pomology at Dr. Y.S. Parmar University of Horticulture and Forestry, Nauni-Solan (H.P.) India. Ten - years - old walnut trees having uniform size and vigour were selected. An experiment was laid out in a randomized block design with three replications. There were 13 treatments $\mathrm{T}_{1}=$ Recommended dose of NPK + FYM (750 g: $375 \mathrm{~g}: 750 \mathrm{~g}$ $+100 \mathrm{~kg}), \mathrm{T}_{2}=$ Three fourths of the recommended NPK 
$+137.5 \mathrm{~kg} \mathrm{FYM}, \mathrm{T}_{3}=$ Half of the recommended NPK + $175 \mathrm{~kg} \mathrm{FYM}, \mathrm{T}_{4}=$ Recommended dose of NPK $+10 \mathrm{~kg}$ neem cake, $T_{5}=$ Three fourths of the recommended $\mathrm{NPK}+13.75 \mathrm{~kg}$ neem cake, $\mathrm{T}_{6}=$ Half of the recommended NPK $+17.5 \mathrm{~kg}$ neem cake, $\mathrm{T}_{7}=$ Recommended dose of NPK $+50 \mathrm{~kg}$ vermicompost, $\mathrm{T}_{8}=$ Three fourths of the recommended NPK $+68.75 \mathrm{~kg}$ vermi-compost, $\mathrm{T}_{9}=$ Half of the recommended NPK + $87.50 \mathrm{~kg}$ vermicompost, $\mathrm{T}_{10}=15 \mathrm{~kg}$ neem cake, $\mathrm{T}_{11}=75$ $\mathrm{kg}$ vermicompost, $\mathrm{T}_{12}=150 \mathrm{~kg}$ FYM, $\mathrm{T}_{13}=$ Recommended dose of NPK .

All the treatments were applied in December 2004. The required amounts of each fertilizer and manure were weighed by weighing balance separately .Fertilizers and manures were applied $30 \mathrm{~cm}$ away from tree trunk by broadcasting in the tree basin area then mixing with the soil and mulching properly. The leaf samples were collected during the first week of August 2005.

\section{Determination of leaf nutrient status \\ Collection and preparation of leaf samples}

Leaf samples from walnut trees were collected and analysed as per standard sampling method. The samples were washed first under tap water followed by $0.1 \mathrm{~N}$ $\mathrm{HCl}$, distilled water and finally with double distilled water. They were then dried by spreading on clean blotting papers and final drying was accomplished in an oven at $68^{\circ} \mathrm{C}$ (Chapman 1964). The samples were sequentially ground by electrical grinder for further analysis.

\section{Digestion of the leaf samples}

The digestion of the samples for the estimation of nitrogen was carried out in concentration sulphuric acid (AR grade ) by adding digestion mixture. For the estimation of leaf $\mathrm{P}, \mathrm{K}, \mathrm{Ca}, \mathrm{Mg}, \mathrm{Zn}, \mathrm{Fe}, \mathrm{Cu}$ and $\mathrm{Mn}$, digestion was done in diacid mixture prepared by mixing nitric acid and perchloric acid (AR grade) in the ratio of $4: 1$.

\section{Determination of nutrient elements}

a) Total nitrogen content was determined by Microkjeldahl's method (AOAC 1980) and results were expressed in percentage on dry weight basis. b) Total phosphorus content was determined by Vanadomolybdophosphoric yellow colour method (Jackson 1975) and the results were expressed in percentage on dry weight basis.

c) Total potassium content was determined by flame photometer (Toshniwal, TMF 45) and the result was expressed in percentage on dry weight basis.

d) The estimation of $\mathrm{Ca}$ and $\mathrm{Mg}$ was done by attomic absorption spectrophotometer.

e) The micronutrients zinc, iron, copper and manganese were also determined with the help of atomic absoption spectrophotometer and the results were expressed in parts per million (ppm) on dry weight basis.

\section{Result and Discussion \\ Leaf nitrogen}

The highest leaf $\mathrm{N}$ content was recorded in treatment recommended dose of NPK $+50 \mathrm{~kg}$ vermicompost and lowest in treatment $150 \mathrm{~kg} \mathrm{FYM}$ (Table 1). This might be due to the fact that application of $50 \mathrm{~kg}$ vermicompost along with full dose of NPK must have enhanced mineralization of organic nitrogen thus making more nitrogen available to the plant. These results are in conformity with the findings of Prasad and Singhania (1989) and Mukherjee et al. (1991) who also reported similar results in Khasi mandarin. Similar results were also reported by Reddy et al. (2001) in coconut seedlings and Shivputra et al.(2004) in papaya.

\section{Leaf phosphorus content}

Leaf $P$ content was affected significantly by different treatments. Maximum leaf $\mathrm{P}$ content was recorded in treatment full NPK $+50 \mathrm{~kg}$ vermicompost and minimum in treatment $15 \mathrm{~kg}$ neem cake (Table 1). Highest leaf $\mathrm{P}$ content in treatment $\mathrm{T}_{7}$ may be attributed to the fact that vermicompost is a rich source of soil micro-organisms which must have helped in the solublization of fixed $\mathrm{P}$ to soluble form thus making it easily available to the plant. These results are in agreement with the findings of Jambhekar et al. (1992) and Shivputra et al. (2004).

\section{Leaf potassium content}

Effect of different treatments of organic, inorganic and their combinations on leaf $\mathrm{K}$ content of walnut was found statistically non-significant. 


\section{Leaf calcium content}

Leaf Ca content was affected significantly by different treatments. Highest leaf Ca content was in treatment half of the recommended NPK $+87.50 \mathrm{~kg}$ vermicompost and lowest in control recommended dose of NPK (750g: 375g: $750 \mathrm{~g}$ ) (Table 1). Similar results were also reported by Rodrignez et al.(2000) in Gerbera. This response could have been due to the fact that vermicompost is a rich source of $\mathrm{Ca}$ and with the application of higher quantity of it, availability of $\mathrm{Ca}$ would have increased hence more leaf Ca content. These results are in confirmation with the findings of Anitha and Prema (2003) who reported more $\mathrm{Ca}$ in vermicompost.

\section{Leaf magnesium content}

The present investigation results clearly indicate that leaf $\mathrm{Mg}$ was affected significantly by different treatments. Treatment half of the recommended NPK $+17.5 \mathrm{~kg}$ neem cake was found superior in increasing leaf $\mathrm{Mg}$ than all other treatments (Table 1). Results also showed that with the increase in neem cake, leaf $\mathrm{Mg}$ content increased, while with the increase in vermicompost leaf $\mathrm{Mg}$ showed declining trend. This reflects that neem cake might be rich source of $\mathrm{Mg}$ content as compared to vermicompost and FYM. These results are in line with the findings of Huchce et al. (2001) who also reported similar results in mandarin.

Table 1. Effect of integrated nutrient management on the macro-nutrient status of walnut leaves.

\begin{tabular}{l|c|c|c|c|c}
\hline \multicolumn{1}{c|}{ Treatment } & $\begin{array}{c}\mathrm{N} \\
(\%)\end{array}$ & $\begin{array}{c}\mathrm{P} \\
(\%)\end{array}$ & $\begin{array}{c}\mathrm{K} \\
(\%)\end{array}$ & $\begin{array}{c}\mathrm{Ca} \\
(\%)\end{array}$ & $\begin{array}{c}\mathrm{Mg} \\
(\%)\end{array}$ \\
\hline $\mathrm{T}_{1}=$ Recommended dose of NPK + FYM(750g :375 g: 750g +100kg) & 2.77 & 0.25 & 1.42 & 2.58 & 0.53 \\
$\mathrm{~T}_{2}=$ Three fourths of the recommended NPK +137.5kg FYM & 2.68 & 0.28 & 1.34 & 2.46 & 0.54 \\
$\mathrm{~T}_{3}=$ Half of the recommended NPK + 175 kg FYM & 2.69 & 0.27 & 1.38 & 2.46 & 0.54 \\
$\mathrm{~T}_{4}=$ Recommended dose of NPK+10kg neem cake & 2.63 & 0.25 & 1.35 & 2.58 & 0.52 \\
$\mathrm{~T}_{5}=$ Three fourths of the recommended NPK+13.75 kg neem cake & 2.67 & 0.26 & 1.39 & 2.49 & 0.59 \\
$\mathrm{~T}_{6}=$ Half of the recommended NPK + 17.5kg neem cake & 2.69 & 0.24 & 1.40 & 2.50 & 0.62 \\
$\mathrm{~T}_{7}=$ Recommended dose of NPK +50kg vermicompost & 2.78 & 0.31 & 1.38 & 2.57 & 0.61 \\
$\mathrm{~T}_{8}=$ Three fourths of the recommended NPK+68.75kg vermi-compost & 2.76 & 0.28 & 1.44 & 2.37 & 0.60 \\
$\mathrm{~T}_{9}=$ Half of the recommended NPK + 87.50kg vermicompost & 2.71 & 0.31 & 1.41 & 2.60 & 0.53 \\
$\mathrm{~T}_{10}=15$ kg neem cake & 2.53 & 0.24 & 1.29 & 2.36 & 0.56 \\
$\mathrm{~T}_{11}=$ 75 kg vermicompost & 2.48 & 0.26 & 1.29 & 2.33 & 0.60 \\
$\mathrm{~T}_{12}=150 \mathrm{~kg}$ FYM & 2.27 & 0.27 & 1.27 & 2.39 & 0.57 \\
$\mathrm{~T}_{13}=$ Recommended dose of NPK & 2.67 & 0.25 & 1.31 & 2.22 & 0.53 \\
\hline \multicolumn{1}{|c|}{ CD 0.05 } & 0.24 & 0.04 & $\mathrm{NS}$ & 0.10 & 0.03 \\
\hline
\end{tabular}

\section{Leaf zinc content}

Maximum leaf $\mathrm{Zn}$ content was recorded in treatment, three fourths of the recommended NPK $+68.75 \mathrm{~kg}$ vermicompost (Table 2). This might be due to the reason that vermicompost in combination with NPK must have improved soil properties like microbial population, enzymatic activities especially dehydrogenase and hydrolase (Chaudhary et al. 2004). With the improvement of these soil characteristics the higher availability of micronutrients especially $\mathrm{Zn}$ and $\mathrm{Mn}$ in vermicompost treated soils may be attributed to the release of organically bound micronutrients present in vermicompost (Lee 1985).

\section{Leaf manganese content}

Leaf Mn content was also recorded maximum in treatment three fourths of the recommended NPK $+68.75 \mathrm{~kg}$ vermicompost (Table 2). This may be attributed due to the improved fertilizer use efficiency with the application of vermicompost (Chaudhary et al. 2004) apart from the nutrient supply and availability. 
Table 2. Effect of integrated nutrient management on the micro-nutrient status of walnut leaves

\begin{tabular}{l|l|l|l|c}
\hline Treatment & Zn(ppm) & Mn(ppm) & Fe(ppm) & Cu(ppm) \\
\hline $\mathrm{T}_{1}=$ Recommended dose of NPK + FYM(750g:375 g: $\left.750 \mathrm{~g}+100 \mathrm{~kg}\right)$ & 23.85 & 36.50 & 135.12 & 3.60 \\
$\mathrm{~T}_{2}=$ Three fourths of the recommended NPK $+137.5 \mathrm{~kg}$ FYM & 26.70 & 51.65 & 112.42 & 4.08 \\
$\mathrm{~T}_{3}=$ Half of the recommended NPK + 175 kg FYM & 28.67 & 35.82 & 106.53 & 3.55 \\
$\mathrm{~T}_{4}=$ Recommended dose of NPK+10kg neem cake & 25.17 & 33.31 & 133.62 & 3.38 \\
$\mathrm{~T}_{5}=$ Three fourths of the recommended NPK+ $13.75 \mathrm{~kg}$ neem cake & 23.72 & 42.98 & 103.72 & 2.60 \\
$\mathrm{~T}_{6}=$ Half of the recommended NPK + 17.5kg neem cake & 22.57 & 46.55 & 113.13 & 2.75 \\
$\mathrm{~T}_{7}=$ Recommended dose of NPK $+50 \mathrm{~kg}$ vermicompost & 27.53 & 33.52 & 109.93 & 4.53 \\
$\mathrm{~T}_{8}=$ Three fourths of the recommended NPK+68.75kgvermi-compost & 29.18 & 53.50 & 120.65 & 4.23 \\
$\mathrm{~T}_{9}=$ Half of the recommended NPK + 87.50kg vermicompost & 27.53 & 42.52 & 116.82 & 2.54 \\
$\mathrm{~T}_{10}=15 \mathrm{~kg}$ neem cake & 19.50 & 39.53 & 105.82 & 2.83 \\
$\mathrm{~T}_{11}=75 \mathrm{~kg}$ vermicompost & 16.50 & 52.25 & 155.67 & 3.43 \\
$\mathrm{~T}_{12}=150 \mathrm{~kg}$ FYM & 23.88 & 34.58 & 124.12 & 3.03 \\
$\mathrm{~T}_{13}=$ Recommended dose of NPK & 23.16 & 32.52 & 119.73 & 2.72 \\
\hline $\mathrm{CD}_{0.05}$ & 2.71 & 2.67 & 22.20 & 0.90 \\
\hline
\end{tabular}

\section{Leaf iron content}

Leaf Fe content was affected significantly by different treatments. Highest leaf Fe content was in treatment 75 $\mathrm{kg}$ vermicompost and lowest in three fourths of the recommended NPK $+13.75 \mathrm{~kg}$ neem cake (Table 2). Highest $\mathrm{Fe}$ content in $75 \mathrm{~kg}$ vermicompost might be due to the positive effect of vermicompost on soil properties thus releasing $\mathrm{Fe}$ to the plant. Addition of vermicompost in the soil increases the availability of micronutrient to plant (Sainz et al. 1998, Vasanthi \& Kumaraswamy, 1999). Venkatesh et al. (1997) in grape field found that application of vermicompost @ $5 \mathrm{t} \mathrm{ha}^{-1}$ Increased $\mathrm{Fe}$ availability to 122.6 percent.

\section{Leaf copper content}

Leaf $\mathrm{Cu}$ content was maximum in treatment recommended dose of NPK $+50 \mathrm{~kg}$ vermicompost (Table 2 ). This again might be due to the improved soil properties, increased microbial population and more solublization of bound nutrients thus making them available freely to the plant. Results are in close confirmity with the findings of Venkatesh et al. (1997) who also reported in grape field that application of $5 \mathrm{t} / \mathrm{ha}^{-1}$. vermicompost increased available $\mathrm{Cu}$ to 194 percent.

Walnut is a most important high value nut crop and has potential in some hills of India and Nepal. According to this research application of recommended dose of NPK
$+50 \mathrm{~kg}$ vermicompost and three fourth of the recommended dose of NPK $+68.75 \mathrm{~kg}$ vermicompost were effective in improving the leaf nutrient status.

\section{Acknowledgement}

We are thankful to Dr. N. K. Joolka, Professor and Head , Department of Pomology, Dr. Y.S. Parmar University of Horticulture and forestry, India for providing the field and lab facilities. We are also very much grateful to Dr. A.S. Rehalia, Dr. P.K. Mahajan, Dr. S.S. Sharma and Dr. Udaya Sharma for their valuable guidance and support.

\section{References}

A O A C. 1980. Official methods of Analysis of the Analytical chemists. (13 ${ }^{\text {th }}$ Ed.) (Ed. W.Horwitz). Association of Official Analytical Chemists. Washington, D.C. $1018 p p$

Anitha, S. and Prema A. 2003. Vermicompost boosts crop production. Indian Farming News 53(8): 15-18.

Chapman, H.D. 1964. Suggested foliar sampling and handling techniques for determining the nutrient status of some field, horticulture and plantation crops. Indian Journal of Horticulture 2: 97-119.

Chaudhary, B.N., Y.R. Panday, B.B. Mahat, C. R. Jaishi and Y.P. Yadav. 2004. Standardization of vegetative propagation on walnut. Advances of Horticultural Research in Nepal. 89-101

Chaudhary, D.R., S.C. Bhandaris and L.M. Shukla. 2004. Role of vermicompost in sustainable agriculture $-\mathrm{A}$ Review. Agriculture Review 25(1): 29-39. 


\section{B.P. Bhattarai \& C.S. Tomar /Effect of Integrated Nutrient.......}

Cochran, G.C. and G M. Cox. 1963. Experimental Design, Asia Publishing House Bombay. pp.611.

FA O. 2007. http: // www.fao.org.

Huchce, A.D., A.R. Lallan Ram, A.R. Srivastava and Shyam Singh. 2001. Effect of coating treatments on urea nitrogen application in Nagpur mandarin (Citrus reticulata, Blanco.).South Indian Horticulture 49 : 119-121

Jackson, M L.1975. Soil chemical analysis . Asia publishing House Bombay. pp.10-205.

Jambhekar, H.A. 1992. Use of earthworms as potential source of decomposed organic wastes. In: Proceedings, National Seminar on Organic Farming. Mahatma Phule Krishi Vidyapeeth, Pune. pp.52-53.

Lee K E. 1985. Earthworms their ecology and relation with soil and land use. Acadamic press, Sydney, pp. $188-194$

Mukherjee, D.S. , Mitra and A.C. Das. 1991. Effect ofoil cake on changes in carbon and microbial population in soil. Journal of Indian Society of Soil Science 39: $457-462$.

Prasad, R.A. and R A. Sighania. 1989. Effect of different types of enriched manures and time of incubation on soil properties. Journal of Indian Society of Soil Science 37: $329-322$.

Reddy, D.V.S., S.N. Kumar and S.R. Prabhu. 2001. Evaluation of alternative media to potting mixture for raising coconut seedlings in polybags. Journal of Plantation Crops 29(1):62-65.

Rodriguez, J.A., Majia-E Zavaleta, P. Sanchez- Garcia and H. Gonalez- Rasas. 2000. Their effect of vermicompost on plant nutrient, yield and incidence of root and crown rot of gerbera(Gerbera jamerosii H. Bolus). Fitopatologia. 35(1): 66-79.

Sainz, M.J., M.T. Toboada and A. Vilarino. 1998. Growth, mineral nutrition and mycorrhizal colonization of red colver and Cucumber plants grown in a soil amended with Composted urban wastes. Plant and Soil 205(1):85-92.

Shivputra, S.S., C.P. Patil, G.S.K. Swamy and P.B. Patil. 2004. Cumulative effect of VAM fungi and vermicompost on nitrogen, phosphorus, potassium and chlorophyll content of papaya leaf. Mycorrhiza News 16(2): 15-16.

Vasanthi, D. and K. Kumaraswamy. 1999. Efficiency of vermicompost to Improve Soil Fertility and Rice yield. Journal of Indian society of Soil Science 47: 268-272.

Venkatesh, P.B. Patil, K.S . Kumar, C.V. Patil and R.S. Giraddi. 1997. Influence of in sate vermiculture and vermicompost on availability and plant content of micronutrients. Advances in Agricultural Research in India 7: 179-183. 
Nepal Journal of Science and Technology 10 (2009) 